\title{
Documenting the significance of the Ibibio traditional marriage gift items: A communicative approach
}

\author{
Bassey Andian Okon ${ }^{1}$, Edemekong Lawson Ekpe ${ }^{1}$, Stella Asibong Ansa ${ }^{2}$ \\ ${ }^{1}$ Department of Linguistics and Communication Studies, University of Calabar, Calabar, Nigeria \\ ${ }^{2}$ Department of English and Literary Studies, University of Calabar, Calabar, Nigeria
}

Email address:

Basseyokon2005@Yahoo.Co.Uk (B. A. Okon), Edemekong@Justice.Com (E. L. Ekpe), Stellaansa@Yahoo.Co.Uk (S. A. Ansa)

To cite this article:

Bassey Andian Okon, Edemekong Lawson Ekpe, Stella Asibong Ansa. Documenting the Significance of the Ibibio Traditional Marriage Gift Items: A Communicative Approach. International Journal of Language and Linguistics. Vol. 2, No. 3, 2014, pp. 181-189.

doi: $10.11648 /$ j.ijl1.20140203.17

\begin{abstract}
Marriage is one of the culture universals being that it is contracted in every society of the world, but its mode of contract varies from one society to the other. This paper unravels the significance and reasons for the traditional marriage gifts in Ibibio traditional marriage. Gifts in general, have meanings attached when given or received but most importantly, they communicate the culture of the people and other forms of emotions. Through this work, the different items given and the significance of the gifts in Ibibio traditional marriage/ culture are shown. The theoretical framework is the semiotic approach which has to do with the science of sign system or signification which is amenable to this paper. This work was a purely qualitative research, where participant observation and unstructured interviews were employed. The scope of the study is the Ibibio ethnic group of Akwa Ibom State of Nigeria.
\end{abstract}

Keywords: Documenting, Traditional Marriage, Gift Items, Communicative, Semiotics

\section{Introduction}

In many societies of the world, marriage is seen as the fundamental unit of the society without which there could be no family. It is said to be the first institution in the history of man. Marriage, as defined by the Wikipedia free Encyclopedia is "a social union or legal contract between people that creates kinship. It is an institution in which interpersonal relationships, usually intimate and sexual, are acknowledged in a variety of ways, depending on the culture subculture in which it is found".

Marriage is usually recognized by the state, a religious authority, or both. It is often viewed as a contract. Thompson and Hickey (2008,p.359) define marriage as " a legally recognized economic and sexual relationship between two or more person (sic) that include mutual rights and obligations and is assumed to be permanent.

On the other hand Nanda and Warms (2009, p.144) view marriage as "the customs, rules, and obligations that establish a socially endorsed relationship between the kin groups of the married partners." Although in most societies marriage and the subsequent formation of families rest on the biological complementarities of male and female in reproduction, both marriage and family are cultural patterns. Thus they differ in form and function both among and within human societies and change over time with changing political and economic circumstances and the life stages of individuals. Charles (2010, p.246) points out that "in Africa, marriage occupies a unique place in human life cycle. It is the pivot of human continuity and attested acid test for maturity... In Africa, marriage creates affinal relationship which is believed to belong to a sacred and higher order of relationship". The view of Charles and others go a long way to show the importance of marriage in the society.

There are certain things that accompany marriage celebration in different cultures; one of such is the presentation of gifts to the couple at the end of the marriage celebration. This work seeks to find out the significance of these gifts since every gift has its significance and meanings attached when given and received. It could signify love, peace, appreciation, threat, show of abundance, anger, but more importantly, it communities the culture of the people and other forms of emotions. Adler, Proctor II and Towne (2005, pp. 135-136) say that "there are differences in the degree to which 
people in various cultures display their feelings... Cultural background influences the way we interpret others emotions as well as express our own." From the foregoing, one can say that interpretation of things and gifts are cultural which is what this research seeks to find out.

\subsection{The Ibibios}

The Ibibio are the people of south-south Nigeria and have lived in Akwa Ibom/ Cross River area of modern day Nigeria for several hundreds of years. They are related to the Anaang and the Efik people. According to the 1991 census, the Ibibio numbered 2.4 million people. The 2006 census estimated their population at 3.9 million. Historically, P. A. Talbot as cited by Ukpong (2007, p.1) estimates that the "Ibibio arrived Southern Nigeria by 7000BC or earlier." M. D. W. Jeffreys is of the view that the Ibibio are more properly classified as Semi -Bantu than Semi-Sudanese. The number of Bantu roots in the Ibibio language, he observes, exceed others by far. It must be emphasized that the Ibibio migration into Nigeria was part of the Bantu expansion. Their original homeland prior to coming to Nigeria was Usak Edet, where they lived along with Oron and perhaps also the Efut at the Nigeria/Cameroon border (Ukpong, 2007).

According to Essien (1990, p. ix) "The Ibibio of Akwa Ibom State constitute the largest ethnic group in Nigeria, after the three major one Hausa, Igbo and Yoruba." The Ibibio's are found in about 16 Local Government Areas of Akwa Ibom State namely; Eket, Esit Eket, Etinan, Ibeno, Ibesikpo Asutan, Ibiono Ibom, Ikono, Ikot Abasi, Ini, Mkpat Enin, Nsit Atai, Nsit Ibom, Onna, Uruan and Uyo.

\subsection{Types of Nigerian Marriages}

There are 3 types of marriages that are practiced in Nigeria- Traditional, Religious (Church/Mosque) and Civil (Court) marriage. A Nigerian couple can decide to take part in one or all of these, and the number usually boils down to culture and wealth. However, the traditional marriage is very important to Nigerians. Civil marriages take place at a government registry office. A religious marriage is one performed according to the customs and traditions of that particular religion. Such marriage takes place either in a church or mosque. Christian males are allowed one wife while Muslim men are allowed up to four wives. Civil marriage only allows one wife as well regardless of religion.

\subsection{Ibibio Traditional Marriage}

Marriage is contracted in every society of the world but its mode of contract varies from one society to the other. Among the Ibibio people, according to Ukpong (2007, p. 143) "marriage is a religious, social and economic responsibility on the part of every human being. It is part of the rhythm of life in which everyone must participate". The institution is regarded as sacred and without which a family cannot be started. In Ibibio, there are stages to the traditional marriage rites and each stage is very significant.

The first stage is known as 'Udiọngọ Ufọk' which means "to know the home". During this stage, two or three people are expected to go with the groom to be, to know the lady's home and of course meet her parents. The bride's family is mandated by custom to cook and entertain the groom's family members like special guests. The groom's family on their part is not expected to visit without some gifts, for example: some bottles of drinks/ wine to give to the family.

The next stage is the "Nkọng Udọk" which mean "Knocking on the door" or introduction. At this stage, since the family of the groom had earlier come to know the home, they are officially coming to ask for the lady's hand in marriage. This time, more people from both families are expected to be present at the occasion. When/if the lady gives her consent/ accept to marry the man, the father of the lady/elders of her family will give the marriage list to the elders of the groom's family. The list is subject to bargaining by the two families. This stage is also full of merriment, as the bride's family usually provides enough to eat and drink.

The last stage is the "Usoro ndo mme edino nkpo $\mathrm{nd}^{\wedge} \eta$ ufok" which means traditional marriage ceremony. When most of the items on the marriage list have been bought by the groom, a date is usually agreed upon by both families when those things will be brought. This is usually a few days to the main occasion and it is so done to save time/avoid delays on the main marriage day. This presentation of items usually does not call for much witnesses or merriment. The traditional marriage day is always very eventful A joyous day for not only the bride and groom but also the family members and friends.

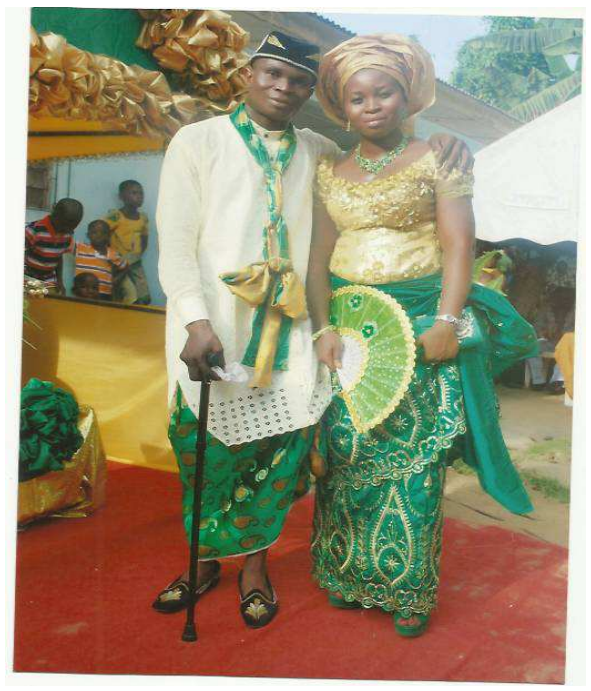

Fig 1. Marriage Between Uduak and Smart. 


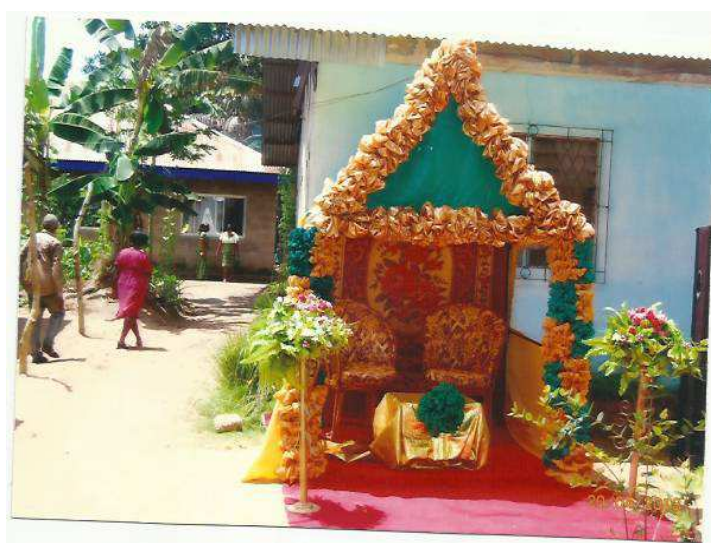

Fig 2. Atayad'-a Hut for the Couple During the Ceremony.

\subsection{Objectives}

To highlight the various stages of Ibibio traditional marriage.

To investigate the different traditional marriage gifts items in Ibibio culture.

To show the significance of the traditional marriage gift items in Ibibio land.

To illustrate the Ibibio traditional cultural values through the marriage gift items.

\subsection{Research Questions}

What is the significance of the traditional marriage gift items?

How do the traditional marriage gift items signify the Ibibio cultural values?

Why is it relevant to document Ibibio traditional gift items?

\subsection{Methodology}

This research work is purely a qualitative work. Interviews were made in the course of this research and participant observation was also employed by the researchers. The researchers give a vivid description of what the gift items are and based on investigation, show the cultural values of the different gift items. About five (5) traditional marriages that took place in different Local Government Areas found in Ibibio land were sampled for this work. The aim was to see if there are variations with the gift items and also to be sure that the scope of the study which is Ibibio land is properly covered. The recipients of the gift items (celebrants) were duly interviewed to seek their opinion and the implication of the gifts they received. The parents/ guardians of the recipients were also interviewed to get their views and to know the rationale behind the gift items. Pictures were taken to show these gift items.

\section{Theoretical Framework}

This research work made use of the semiotic theory. Semiotics is often said to derive from two sources: F de Saussure and C. S. Peirce. This theory deals with the production and interpretation of meaning. Its basic principle is that meaning is made by the deployment of acts and objects which function as "Signs". Martin and Ringham (2006, p. 175) say that "this theory is based on the belief that meaning is not inherent in objects, that they do not signify by themselves, but that meaning is constructed by a competent observer-a subject capable of giving 'forms' to objects". According to University of Twente (Utwente), there are two major approaches to semiotics. Saussure's approach was a generalization of formal, structuralist linguistics, whereas Peirce's was an extension of reasoning and logic in natural sciences. General semiotics tend to be formalistic, abstracting signs from the contexts of use and on the other hand, social semiotics takes the meaning-making process-"Semiosis,"to be more fundamental than the system of meaning relations among signs, which are considered to be the only resources to be employed in making meaning. Oregon State University on their part states thus: "based on "semiosis", it's the relationship between a sign, an object, and a meaning. The sign represents the object, or the referent, in the mind of an interpreter. "Interpretant" refers to a sign that serves as the representation of an object. Signs can be verbal or non-verbal. According to them people are interpreters of signs. Signs have three factors that guide interpretation. The DESIGNATIVE aspect directs the interpreter to a particular object.

The APPRAISIVE aspect highlights object qualities, enabling evaluation. The PRESCRIPTIVE aspect directs one to respond in specific ways. These three aspects that guide interpretation are important to this work as they will guide in the data analysis.

Utwente further states that "social semiotics examines semiotic practices specific to culture and community, for the making of various kinds of texts and meanings in various situational contexts and contexts of culturally meaningful activity". It is on this premise that the researchers of this work assert that social semiotics is of relevance to this work since the work has to do with the significance of traditional marriage gift items. Marriage as it is widely known is culture universal therefore one cannot be talking about marriage in isolation from culture.

The concept of 'sign system' and 'signification' is used in somewhat different ways by theorists but the following are the essentials as shown in the diagram below.

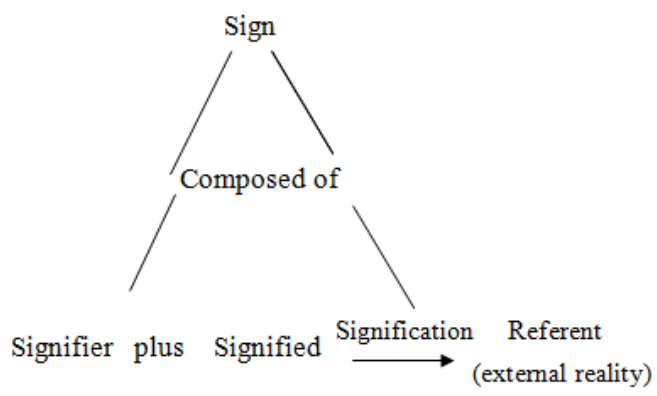

Fig 3. Elements of Semiology, Source: Mc Quail (2010, p.346). 
Sign in meaning systems have two elements: physical plus associated meaning in the culture and in use. According to Mc Quails (2010, p. 346), "A sign is the basic physical vehicle of meaning in a language; it is any 'sound image' that we can hear or see and which we wish to communicate, which is known as the referent.

In human communication, we use signs to convey meanings about objects in the world of experience to others, who interpret the signs we use on the basis of sharing the same language or knowledge of the sign system we are using. De Saussure as cited by Ringham (2006) and Mc Quail (2010) argue that the process of signification is accomplished by two elements of the sign. He called the physical element (word, image, sound) the 'signifier and used the term 'signified' to refer to the mental concept invoked by a physical sign in a given language code, and in this case the Ibibio language. Mc Quail further adds that normally in language systems, the connection between a physical signifier (such as a word) and a particular referent is arbitrary, but the relation between signifier and signified (meaning or concept conveyed) is governed by the rules of culture and has to be learned by the particular 'interpretative community'.

To further show that attribution of meaning to an object or image is culture bound and the very issue which this work tries to unravel, ECO (1979) puts it thus: "What then, is the meaning of a term? From a semiotic point of view it can only be a 'cultural unit'. In every culture, a unit... is simply anything that is culturally defined and distinguished as an entity. It may be a person, place, thing, feeling, state of affairs, sense of foreboding, fantasy, hallucination, etc...such units and arts are cultural units".

The major point of relevance of this theory to this study is the recognition given to culture as an aspect in the derivation of meaning of an object, entity or image. Since the significance of traditional marriage gift items which is the crux of this work cannot be studied in isolation but as an aspect of Ibibio culture, semiotic theory is of great essence.

\subsection{Symbolism}

The aim of this work is to bring to the fore the traditional marriage gift items in Ibibio and to also show the symbolism of each of the gift items. Since African cultural identity seems to be in crisis, this work will help in finding ways of healing it through symbols discovered in Ibibio cultural setting.

The term symbolism according to the Wikipedia free Encyclopedia is the practice of representing things by means of symbols or of attributing symbolic meanings or significance to objects, events, or relationship. Isiguzo (ND) on his part sees symbol as something such as idea, object, conventional or non conventional that is used to represent something else. It could be abstract or not. Abstract symbols are symbols that do not depend on their concrete material substance. Non-abstract symbol on the other hand, is when there is a strong link between the reference and the referent. This work, documenting the significance of the Ibibio Traditional marriage Gift items has to do more with non-abstract symbols.

The Ibibio world view is replete with symbols. Dzobo as cited by Isiguzo notes that "African symbols are sources of insights into African orientation to life". By this, one can infer that the Ibibio traditional marriage gift items, give knowledge into the Ibibio world view.

\section{Ibibio Language and Culture}

Generally, the Ibibio language belongs to the BenueCongo sub family which in turn belongs to the Niger Congo family, one of the largest families of languages in Africa. Greenberg's (1963) and Essien's (1990) classifications show it belongs to the Lower Cross group.

According to Udoh and Okon (2008, p 39) "The Ibibio language is a fairly developed language. It has had orthography since 1983 . The orthography paved the way for several publications in the language" The Ibibio language is very important in this work because apart from it being an element of culture, it is through language that culture is conveyed/expressed.

Haliday (1993, p.36) agrees to this as he cites Bernstein 1971 's view which says that " in order to understand the social system, how it persists and changes in the course of the transmission of culture from one generation to another, you have to understand the key role that language plays in this". Lyons 2005 as cited by Okon, Ekpe, Ansa and Udoinyang (2009, p. 312) further emphasize the importance of language thus; "...the institution whereby humans communicate and interact with each other..." Based on this definition, language as an institution is all embracing and other issues in the society are subsumed in it. Its embodiment of other issues includes the act and arts of communication such as the traditional marriage gift items which this work deals with.

However, culture on the other hand is "the learned set of beliefs, values norms, and material goods shared by group members... culture has two major components: material and non-material culture. Material culture includes artifacts, art, architecture, and other tangible goods that people create and assign meanings... Non material culture refers to mental blue-prints that serve as guidelines for group behaviour". Thompson and Hickey (2008, p.57).

For this work, much attention will be given to material culture since tangible goods, in this case the Ibibio traditional marriage gift items will be dealt with. However, material and non material culture are interrelated in that all societies express their beliefs, values and understandings in artifacts, architecture, and art. Ibibio has a rich cultural heritage of both material and nonmaterial components ranging from our food, clothing, music, arts, language, beliefs, marriages and so forth. It is the importance of the Ibibio culture that prompted this work because the significance of the Ibibio traditional marriage gift items has to be documented for our younger generation who now 
place little or no value on them and also to document the richness and interpretation of this culture.

\section{Data Presentation, Analysis and Discussion}

In this section, the different gift items in Ibibio land are highlighted with their different functions. The rationale behind the different gifts is also brought to the fore. The different people interviewed are also recorded. Apart from the Ibibio culture, other cultures were also investigated to view their opinion on the marriage gifts. Such cultures are the Anaang culture in Akwa Ibom State which is slightly close to the Ibibio, the Ejagham and Mbembe cultures that are found in Cross River State as well as the Igbo culture in Anambra State.

Semiotic communication of some of the traditional gift items (Nkpọ nd^n ufọk) are hereby discussed. The three aspects of semiotic theory that guide interpretation of symbols which are designative, appraisive, and prescriptive are put to work here.

\section{Table 1. Data Presentation}

\begin{tabular}{|c|c|c|}
\hline Designative & Appraisive & Prescriptive \\
\hline Plantain sucker & $\begin{array}{l}\text { It is a plant that grows and multiplies. It rarely dies, } \\
\text { flourishes and serves as food for the family. }\end{array}$ & $\begin{array}{l}\text { It stands for fertility longevity and encourages farming. } \\
\text { Symbolizes the value, the Ibibio's place on timeliness in a } \\
\text { family's life and growth. }\end{array}$ \\
\hline Matchete 'Afid' & $\begin{array}{l}\text { Large flat metal with sharp blade used for cutting/ } \\
\text { clearing bush. Also used as a weapon }\end{array}$ & $\begin{array}{l}\text { Promotes hand work, agriculture and protection of the wife and } \\
\text { children from danger. }\end{array}$ \\
\hline $\begin{array}{l}\text { "Esio Usang garri” Iron pot } \\
\text { for frying garri }\end{array}$ & $\begin{array}{l}\text { A big round iron pot for frying garri and to cook } \\
\text { for occasions. }\end{array}$ & $\begin{array}{l}\text { Signifies industry, hard work, economic growth, } \\
\text { saving/investments and communal life. }\end{array}$ \\
\hline 'Ified / Ndiyang & A type of broom made from palm fruit husk & $\begin{array}{l}\text { It communicates cleanliness and tidiness. Shows the wife as a } \\
\text { home maker. }\end{array}$ \\
\hline 'Ifim’ Kitchen stool & $\begin{array}{l}\text { A short wooden stool. Used in the kitchen by } \\
\text { women. }\end{array}$ & $\begin{array}{l}\text { Signifies motherhood, home maker, and also stands for fertility. } \\
\text { It communicates gossip as a nature of women. }\end{array}$ \\
\hline She goat/chick & Domestic animals that can be reared. & $\begin{array}{l}\text { They symbolize fertility and also serve as a form of investment } \\
\text { and savings. }\end{array}$ \\
\hline $\begin{array}{l}\text { Coconut seedlings/ Pine } \\
\text { apple suckers }\end{array}$ & They are fruit plants that flourish and serve as food. & $\begin{array}{l}\text { Longevity and also serve as calendar to mark anniversaries. The } \\
\text { plants serve economic purpose, investment and for boundary } \\
\text { demarcation. }\end{array}$ \\
\hline $\begin{array}{l}\text { 'Abang' Earthen pot/ } \\
\text { plastic pot }\end{array}$ & Big pots that hold water for domestic use. & $\begin{array}{l}\text { Signifies the ambience of a home. Could be seen as African } \\
\text { refrigerator and the water from it has a healing ability. }\end{array}$ \\
\hline 'Aman akama' & Big round basin for bathing baby & $\begin{array}{l}\text { It is a symbol of fertility, longevity and survival of the new born } \\
\text { babies. }\end{array}$ \\
\hline Bible & A holy book for Christians & $\begin{array}{l}\text { Symbolizes globalization. It also shows the movement towards } \\
\text { Christian doctrine and matrimonial laws. }\end{array}$ \\
\hline Sewing machine & A machine used for sewing. & $\begin{array}{l}\text { It signifies hard work, home making and industry. It also shows } \\
\text { contemporary nature of the society and globalization. }\end{array}$ \\
\hline 'Udọk’ Hoe & $\begin{array}{l}\text { Weeding hoe with wooden or metal handle used for } \\
\text { weeding. }\end{array}$ & $\begin{array}{l}\text { Symbolizes hard work and shows the main occupation of the } \\
\text { Ibibio which is farming. It also shows neatness. }\end{array}$ \\
\hline Mortar / Pestle & $\begin{array}{l}\text { Round wooden mortar and wooden pestle used for } \\
\text { pounding. }\end{array}$ & It signifies unity, togetherness and shows the woman as a shield. \\
\hline 'Ik ^ k' /'mbid' & $\begin{array}{l}\text { Bamboo bed/ mat made from raffia which serves as } \\
\text { bed. }\end{array}$ & $\begin{array}{l}\text { It signifies home, love and family. It also symbolizes } \\
\text { procreation. }\end{array}$ \\
\hline 'Okpo ebod' He goat & A mature goat that can be eaten. & $\begin{array}{l}\text { It shows there should be copulation and multiplication. It also } \\
\text { serves economic purpose. }\end{array}$ \\
\hline
\end{tabular}

In all the gift items received by the couples, it could be noticed, that there are some items that recur irrespective of the family and the Local Government Areas in Ibibio land and in the cultures we have looked at. These gift items are goats, sewing machines, brooms, water drums, pots, plantain suckers, coconut seedlings, tubers of yam, etc. These items symbolize the sociological values of the Ibibio and other cultures.

\section{Conclusion}

This research has brought to the fore the different gift items with their significance as found in Ibibio culture. It has also discovered that there is a gradual change from the traditional gift items like 'Esio Ukwak' - iron pot to aluminum pots, earthen pots to refrigerators, wooden spoons to metal spoons, and so forth. It has also documented some gift items which are no longer given or used, for example 'ified' - a type of short broom derived from the palm bunch. Some of these items are being replaced with more modern ones because of life-style change towards contemporary/modern life. In spite of giving gift items to the daughters, the families also consider the sons-in-law by giving a machete for protecting the wife/family. The different gift items symbolize the cultural values of the Ibibio. As shown in these gifts items, one could say that there is a shift from the agrarian society to a more contemporary one thereby bridging the digital divide. 


\section{Acknowledgement}

We wish to acknowledge the Endangered Language Documentation Project (ELDP) for their support in this work and also our informants for their useful information and contribution.

\section{List of People Interviewed}

\section{Ibibio Culture}

Interviewee: Mrs Uduak Smart Daniel Nee Usen $\left(20^{\text {th }}\right.$ April 2013) Afaha Akpan Eno-Etinan L. G. A.

\section{Gift Items}

'Esio ' - Set of Pots

'udun - Mortar/Pestle: To Pound yam, pepper, crayfish,

'afan', etc and not to blend

'Esio' garri - Iron pot for frying garri.

*Kettle - for boiling water

*Water/Food Flask-for preserving food

Plates/Cups - for husband's food

Enamel tray and cutting stick - for chopping vegetable, meat, etc.

'Mfiok'-Tripod stand: Used for cooking

'Obufum' - Native tray made of raffia: For drying crayfish

*Spoon Carrier - for holding cutleries

* Plate rack: For holding plates

* Refrigerators: For storage/ preservation

* Gas cooker/ Cylinder: Cooking

*Microwave Oven: For warming food

* Mattress and 2 pillows, bedsheets/ pillow cases: sleeping

Baby's bath -for bathing children

* Sewing machine - for sewing

'Okwok' - Grater - for grating

'Efa'-Spatula- For turning food

'Ayan' - Broom - for sweeping

'Ified' A type of short broom made for palm fruit bunch:

for sweeping

* Mop - for cleaning

* Bible -To learn/study the word of God and to uphold her home

He goat - eating

She - goat for rearing

Pineapple/ Plantain sucker - for planting

It could be noted that the asterisked items are contemporary things which show a blend of modern and local culture.

According to her, the husband was given a portion of land by members of his family where the suckers could be planted. Their husband appreciated her family and counted himself as blessed. The she-goat will reproduce and bring income to the home. Another significance is that as "Adiaha" first daughter she was thus favoured by her parents because she was submissive, obedient and chaste showing her siblings that they should follow her footsteps.
However, her mother Mrs Eno Eno-obong Utin gave the rationale for giving her daughter those items.

-To go and start a new home and new life

-As a female child, she should use those things and take care of her home.

-She should not go borrowing from her neighbour since she has those things.

-Anytime she needs to work at home, she will not have any excuse for not doing so.

-To be honoured in the home she is going into.

-Her husband would respect her and recognize the fact that she is from a home.

-It is a mother's responsibility to provide the daughter with a home.

-She has given respect to her mother and family.

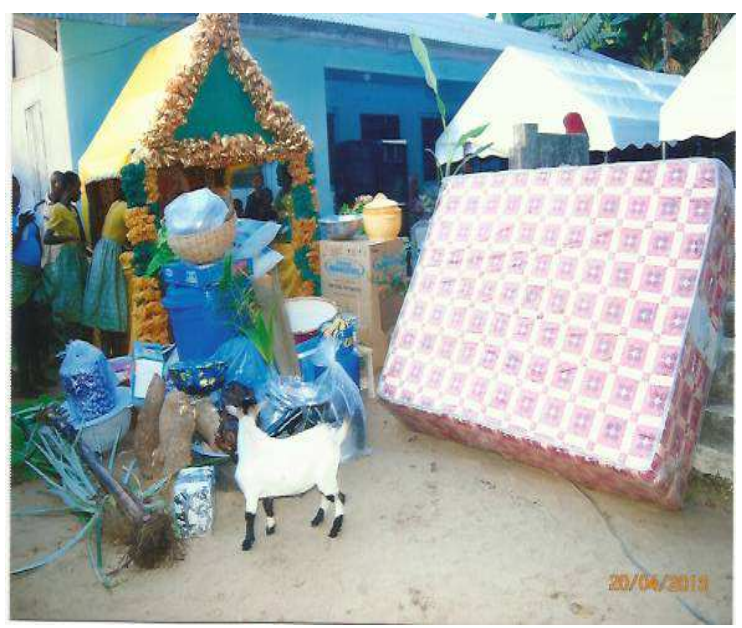

Fig 4. Picture of Gift Items Presented to Mrs Uduak Smart.

\section{Gift Items}

'Esio Ukwak'-Iron Pot: To cook for newly wed's large house hold especially during occasion e.g. child naming ceremony, festivities etc.

"Ediyook"-Local chopping board: useful for cooking, cutting of vegetables and meat.

"Efa" - Spatula: for turning of soup and mixing the ingredients making garri, fufu and other staples.

'Akebe' - Box for clothes: Presented to the bride for storage of wrappers that her husband will give her in future and for cleanliness/tidiness

"Aman akama" - Large enamel basin: Given to the bride in preparation for her newly born babies and it also stands for fertility.

"Esio Usan garri"-Pot for frying garri: To be used for frying garri $-\mathrm{a}$ staple food among the Ibibio and for economic purpose.

"Okpo ebod" - He-got: For immediate consumption for the couple.

"Eto iyak"- A stick of fish (dried)- for consumption

"Isobia-A set of five tubers of yam for consumption

"Uyed - native scrubbing sponge made from coconut husk: for scrubbing pots. It stands for cleanliness. 
"ọkpọk/Ukpakọ" - Used for frying garri for economic/family consumption.

"Ikad" - A roundish cane/ metal basket: for storage of food items e.g. dry fish, meat, grains, native seasonings, etc.

"Ified" - A short husk derived from palm bunch -for sweeping, cleanliness and malnutrition or any children's diseases.

"Ifim" - Kitchen Stool: To sit and prepare dishes for the home and other domestic chores.

"Ayan"-broom made from palm fronds: used to sweep/remove cobweb.

"Afid" - Matchet for clearing the environment, farming and gardening.

"Udọk" - Hoe: For keeping the environs tidy and farming.

"Aban"-Water Pot: for storage

"Mfiọk" - Tripod stand for cooking with firewood.

"Ektd" - Axe: for splitting firewood for domestic/ commercial purposes.

"ọkwọk" - Grater- Two types: a big one for grating cassava and small one for wateryam, cocoyam, coconut, etc.

"Ukeng" - Sieve: Used for processing cassava for frying and for washing cassava used in making fufu.

Mortar/Pestle: For pounding food items. A big one for yam/fufu and small one for grains, pepper and crayfish.

Spoons: for domestic use (Big/Small)

Pots: For cooking

Plates- Sets of plates-for serving household and a set for husband.

"Nai-Nai"- Tray: For serving and picking grains.

Set of glasses: For drinking.

Coconut Seedling: For planting for domestic/economic purposes: It also stands for fruitfulness/fertility.

Hen: for domestic consumption/ economic and also for fertility

She-goat: It stands for economic growth and fertility.

Plantain sucker: For economic reasons, it stands for fertility/increase and it is also used for boundary separation.

Sewing machine: Though it is contemporary, it has always been included since the advent of the Europeans / Modern Education. It serves both domestic / economic purposes.

Interviewee: Mrs Edemekong Lawson Ekpe nee Esara (12/6/2013) Oku-Iboku, Itu, L. G. A. Akwa Ibom State. Marriage Date $-18^{\text {th }}$ October, 2007.

On her part, she gives the significance and relevance of the gifts she got from her parents.

\section{Significance}

She is married to a non-Ibibio person. It was a way of showing Ibibio cultural values which were strange to those from her husband's place. It enabled them to appreciate Ibibio culture. She saw the gift as the way her parents could appreciate her as a good and faithful daughter who did not bring shame to the family.

\section{Cultural Values}

She said the hen and she-goat stands for fruitfulness, procreation and fertility. The hoe and machete show that she has to be industrious not lazy because the Ibibio's are not lazy people. She has to be a good ambassador of her ethnic group. The plantain, yam, coconut, chicken, goat are items of agricultural value. The cooking pots, drinking pot, plates, etc, show that she should be a good home maker.

\section{Relevance}

In her opinion, she said that generations yet unborn may not know the Ibibio gift items so giving them as gift items help in preservation. The present crop of young generation does not appreciate these gift items. They see them as archaic and outdated and therefore do not know nor appreciate their culture. They now opt for items like microwave oven, refrigerator, and vacuum cleaner among others. Other people from other ethnic groups in Nigeria and from other countries will go to know and appreciate the Ibibio's and her culture. Another relevance of these gifts is that there will be respect to family name, integrity and character, discipline, order, essence of culture, strong values, virtue, contentment, love and the ability to manage.

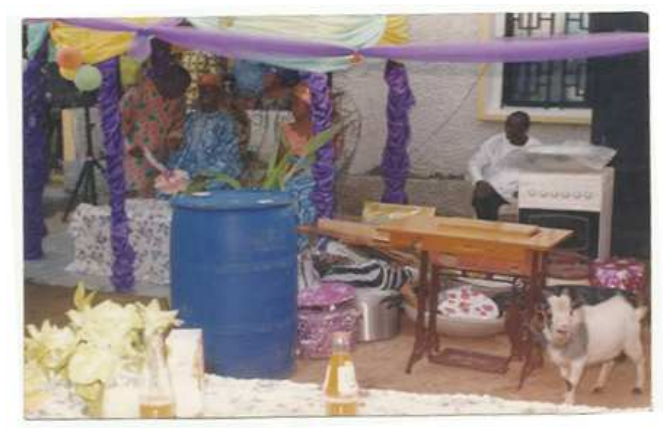

Fig 5. Picture of Mrs Edemekong Ekpe.

\section{Anaang Culture}

Interviewee: Ekediama E. Udo (11/4/2013)

\section{Gift Items}

“ Abaikpa ebod/'unen'- female goat/hen- It stands for fertility and also aid in their income as the goats/hen will reproduce and could be sold to pay children's fees.".

"Esio Mbad'. - Breakable pot: Cooking and keeping food warm which makes the marriage to last long and also to conform that the way to a man's heart is through the stomach.

"Ukeך" - Sifter: for sieving garri

"Ekamba basin": Basin for children's bath and also for wishing her fruitfulness. It is also used for water storage.

Children's bath - For bathing baby and washing clothes.

"If tm"/" akada" - Kitchen stool: for the woman to sit and cook and also sit on it to massage the waist after delivery. 
"ekamba abang" - Big pot: for drinking water, sharing from the same pot brings unity

"Plantain Sucker": For fruitfulness/income: to provide food for the family and also used for demarcation of boundary.

Tripod stand for cooking: For cooking to maintain the family.

Mortar/ Pestle: For pounding.

Coconut seedling: For planting

Broom: For sweeping the floor.

'Ikwa'/Udọk' - Matchete/Hoe - To be industrious and farm to support the husband. Machete is also used in protecting the wife from attacks.

'Usan mbad'/ekpan eto' - breakable plates, wooden spoon, spatula -for cooking and serving

Taking a look at the Anaang gift items and their significance, one could say that they are quite similar to that of the Ibibio's.

Interviewee: Mrs Enobong Emmanuel nee Esara (June 5, 2013 marriage date $27^{\text {th }}$ June, 2009).

\section{Gift Items}

Yam - For consumption

Coconut seedling - For planting

Palm fruit seedling -For planting and for economic/ domestic use

Refrigerator - For preservation.

Water drum - For storage of water

Sewing machine - For domestic and economic purposes.

Dust bin - it shows neatness on the part of the woman.

Grater/ Seive-for processing cassava for both domestic and commercial purposes

The recipient expressed delight and thanked her parents for providing those gifts. Her husband, $\mathrm{Mr}$ Samuel Emmanuel said that he feels honoured to be given those things and that it would help them to start a new home.

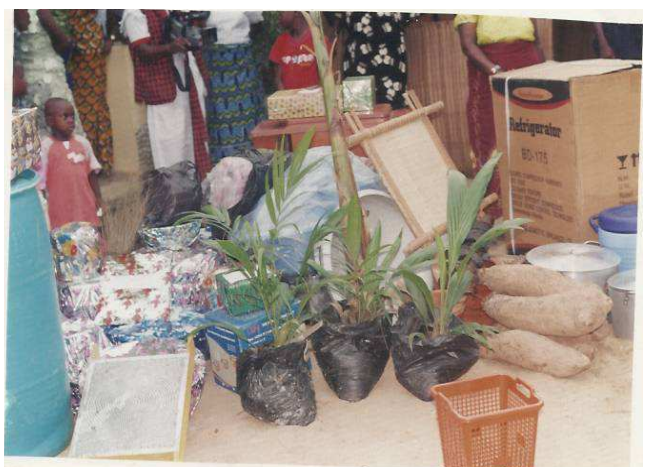

Fig 6. Picture of Mrs Enobong Emmanuel'S Gift Items.

\section{Mbembe Culture}

Interviewee: Christian Owute (male) (10/4/2013)

\section{Gift Items}

Wrapper: for dressing Jewelleries: For beautification
Aluminium Box: For putting and keeping clothes Sewing machine for domestic/ economic purpose Beads: Ornaments

Mortar/ Pestle: For pounding

Yams: for consumption

Pot for frying garri for both domestic and economic purpose.

Tripod Stand for cooking

It is worthy of note that in this culture, the above gifts are given to the bride by the groom (husband). In Ibibio culture, the gift items are exclusively given by the parents / guardians of the bride.

\section{Gifts from the Family}

Basin - For farming. A bride is encouraged to go with a basin in order to do her farming there

Yam - For consumption

Garri - For consumption

Palm Oil - For consumption

Wrapper - For dressing

A look at the above gifts items shows a great difference and sharp contrast from the Ibibio culture.

\section{Ejagham Culture}

Interviewee: Ogar Okang male (April 10 2013)

\section{Gift Items}

Cooking pots (big/small) - for cooking

Earthen Pot: For storing water (African refrigerator) it is seen to be medicinal.

The earth beneath it is robbed on forehead for healing.

Plantain Sucker: Plantain lasts for generations and serves as boundary. It is a staple food for the people.

Hen: It is for animal husbandry and also serves economic purpose. It confirms the Ejagham proverb "Okpa Okona nkoga "meaning - Have a hen no matter the level of poverty". Hen is an asset.

Mortar/Pestle- For pounding: It represents Kitchen ability, without it a woman is incomplete.

Broom: For sweeping, it shows cleanliness.

Tripod stand for cooking: Shows the woman's ability to keep the home warm and free from hunger.

Coconut: Planted to represent an event, indicates an anniversary and mark dates. Matchetes/Hoes: For farming. Farming is occupation for women. It reflects strength and ability to work hard, so that the family does not starve. Ejagham Proverb "Etika Okpehe, etika ibi" meaning if you work hard, though a slave you eat like a king.

Kitchen Stool: To sit and dish food for the family members. It stands for organization and coordination.

Spatula: For turning food

The gift items from Ejagham culture and their significance are quite close to the Ibibio. They are also presented to the bride by the parents/ guardians. It shows similarity in culture though from a different state. 


\section{Igbo Culture}

Interviewee: Mrs Tina O. Onuchukwu (July 5, 2013) Ekwusigo L.G.A Anambra State. Marriage Date August 2003

\section{Gift Item (Idung - Things for the Home)}

Broom: For sweeping

Mortar/Pestle: For pounding

She-goat: For rearing for economic/ domestic purposes

Pots: For cooking

Wrapper: For dressing

The gift items from Igbo culture show that they are things for a homemaker. The similarity with the Ibibio culture is that the gift items are also given to the celebrant by the parents/guardians. It is also note worthy that the gift items have significance just as they have in the other cultures that have been discussed.

\section{Appendix}

Traditional Marriage Gift Items - Nkpo Nd ^ n Ufọk

Plantain Sucker

Goat (Small female)

Hen (Chick)

Coconut seedlings

Spoons/ Pots/ Plates/ Tray/ Cups

Mortar/ Pestle

Grater/ Sifter / Sieve

Tripod Stand for cooking

Water Pot

Brooms/ Matchetes/ Hoes

Kitchen Stool (ifim)

Sewing Machine

Ikad (Cane/metal basket)

ọppọk/Ukpakọ

Uyed - Local sponge

Iso Abia-a set of five tubers of yam

Eto Iyak - (Stick of fish)

Okpo ebot (He goat)

Esio Usan garri - Pot for frying garri

Aman akama (Big enamel basin)

Mattress

Cloth Box (Akebe)

Efa - (spatula)

Local chopping board (ediyọọk)

Esio ukwak - (Iron pot)

Ek $\wedge d($ axe)

Nai-nai (tray)
Ik $\wedge \mathrm{k} /$ mkpana $-\mathrm{A}$ wooden bed made with bamboo

\section{References}

[1] Adler, R., Proctor II, R. and Towne, N. (2005) Looking out looking in. USA: Thomson Wadsworth.

[2] Charles, J. (2010) Ethnography of African Societies: SubSaharan Region. Calabar: Serenity Publishers.

[3] Eco, U. (1979) A Theory of Semiotics. Bloomington: Indiana University Press.

[4] Essien, O. (1990) A Grammar of the Ibibio Language, Ibadan: University Press Ltd.

[5] Halliday, M (1993) Language as social semiotic: The social interpretation of language and meaning, Great Britain: Edward Arnold.

[6] Martin, B. and Ringham, F. (2006) Key Terms in Semiotics. Great Britain: MPG Books Ltd.

[7] Mc Quail, D. (2010) Mass Communication Theory. Los Angeles, SAGE Publications Ltd.

[8] Nanda, S and Warms, R. (2009) Culture Counts: A concise Introduction to cultural anthropology. USA: Wadsworth.

[9] Okon, B., Ekpe., E., Ansa., S., and Udoinyang M. (2009) “A documentation of Ibibio Oramedia" In Adika, G., Fabunmi, F. and Salawu, A. (Eds) Current Prespectives in PhonoSyntax and Dialectology. Accra: Black Mask Ltd. Pp 309324.

[10] Semiotic Theories-Oregon State University Oregonstate.edu/semiotics.htm Retrieved on June 112013.

[11] Semiotic Theories www.utwente.nl/ew/thorie_enoverzic Retrieved on June 11, 2013.

[12] Thompson, W. and Hickey J. (2008). Society in focus: An introduction to sociology. USA: Pearson Education, Inc.

[13] Udoh, I. and Okon, B. (2008). The Language of the Niger Delta Region of Nigeria. Lagos: Concept Publications Ltd.

[14] Ukpong, E. (2007) An Enquiry into culture, Ibibio Names. Uyo: Dorand Publishers.

[15] Wikipedia the free encyclopedia en.wikipedia.org/wiki/marriage. Retreived in September 20 2012.

[16] Isiguzo, A. (No Date) "African Culture and Symbolism: A Rediscovery of the seam of a fragmented identity.

[17] www.crpv.org/seminar/05-sem Retrieved on January 13 2014. 